\title{
IMHOF, Arthur E., Ars vivendi. Von der Kunst, das Paradies auf Erden zu finden
}

\section{Gérald Chaix}

\section{OpenEdition}

\section{Journals}

Édition électronique

URL : http://journals.openedition.org/ifha/2100

DOI : $10.4000 /$ ifha. 2100

ISSN : 2198-8943

\section{Éditeur}

IFRA - Institut franco-allemand (sciences historiques et sociales)

Référence électronique

Gérald Chaix, «IMHOF, Arthur E., Ars vivendi. Von der Kunst, das Paradies auf Erden zu finden », Revue de I'IFHA [En ligne], Date de recension, mis en ligne le 01 janvier 1993, consulté le 22 septembre 2020. URL : http://journals.openedition.org/ifha/2100 ; DOI : https://doi.org/10.4000/ifha.2100

Ce document a été généré automatiquement le 22 septembre 2020

(CIFHA 


\title{
IMHOF, Arthur E., Ars vivendi. Von der Kunst, das Paradies auf Erden zu finden
}

\author{
Gérald Chaix
}

1 L'inclassable A.E. Imhof est bien connu des lecteurs du Bulletin grâce au bref mais incisif article que lui avait consacré Isabelle von Bueltzingsloewen dans le numéro de juin 1990. Continuant une réflexion située aux confins de l'histoire, de la philosophie et de l'éthique, ne cessant de mettre en oeuvre une information qui emprunte aussi bien à la démographie historique qu'à des disciplines aussi différentes que les mathématiques, l'histoire de l'art, l'histoire de la médecine, l'ethnologie, la psychologie, ce dernier ouvrage d'A.E.I. est le pendant de l'Ars moriendi. Die Kunst des Sterbens einst und heute, publié dans cette même collection en 1991.

2 Bénéficiant - du moins dans les pays " développés "- d'une espérance de vie sans commune mesure avec celle de nos ancêtres, sachant que notre vie ne se finira selon toute vraisemblance qu'au quatrième âge, nous n'avons plus seulement, selon l'A., à apprendre un (nouvel) art de mourir, - toujours nécessaire du fait que la sécularisation de la foi a largement entamé la croyance en une vie dans l'au-delà et que nous vivons dans un monde de plus en plus marqué par la présence de l'Islam $(17,7 \%$ de la population en 1985 , sans doute $40,1 \%$ en 2100 , tandis que la part de la population chrétienne passerait dans le même temps de de $30,2 \%$ à $20,2 \%$ ) - mais, également l'art de vivre: savoir désormais trouver le paradis sur terre. Un vrai livre d'histoire. Mais aussi une profonde méditation.

Gérald CHAIX 